\title{
Enkapsulasi Probiotik Lactobacillus sp.Menggunakan Dua Tahap Proses
}

\author{
Rintan Fransiska Trimudita ${ }^{1 *}$, Djaenudin ${ }^{2}$ \\ ${ }^{1}$ Loka Penelitian Teknologi Bersih - Lembaga Ilmu Pengetahuan Indonesia (LPTB-LIPI) Bandung \\ ${ }^{2}$ Jurusan Farmasi, Fakultas Matematika dan Ilmu Pengetahuan Alam, Universitas Garut \\ Gedung 50 - Kampus LIPI Jl. Cisitu Sangkuriang Bandung 40135 \\ *Koresponden email: rintanfransiskatrimudita@gmail.com, aburizki@gmail.com
}

Diterima: 4 Maret 2021

Disetujui: 18 Maret 2021

\begin{abstract}
The Lactobacillus sp. a probiotic microorganism that can't survive gastric acidity and concentration of bile salts in the gastrointestinal tract. Probiotic encapsulation is one of the methods to protect probiotics during the processing, storage, and from acidic solutions in the gastrointestinal tract. The research was to know that viability was encrypted with an alginate matrix and we were against tests in simulated stomach acid. In this research, the encapsulation process was performed by mixing Lactobacillus sp. with NaAlginate to form a suspension as an encapsulation material. The microcapsules formed were coated with chitosan with concentrations i.e., $1.2 \%$; $1.6 \%$; and $2 \%$. Lactobacillus sp. encapsulated chitosan matrix viability was tested in gastric fluid simulation $(0,2 \% \mathrm{NaCl} \mathrm{pH} \mathrm{1,2} \mathrm{and} \mathrm{3)} \mathrm{for} 1$ minute, 60 minutes, and 120 minutes using the TPC method (Total Plate Count). After the viability test, Lactobacillus sp. encapsulated with $2 \%$ chitosan could maintain the viability Lactobacillus sp. with the number of colonies was of 7,41 $\log \mathrm{Cfu} / \mathrm{gram}$ in the simulation of gastric acid fluid $\mathrm{pH} 3$ for 120 minutes, and 4,78 $\log$ $\mathrm{Cfu} / \mathrm{gram}$ in the gastric acid fluid simulation $\mathrm{pH} 1,2$ with a duration 120 minutes.
\end{abstract}

Keywords : probiotics, encapsulation, lactobacillus sp., na-alginate, chitosan

\begin{abstract}
Abstrak
Lactobacillus sp. merupakan mikroorganisme probiotik yang tidak dapat bertahan hidup pada tingkat keasaman lambung dan konsentrasi garam empedu pada saluran cerna. Enkapsulasi probiotik merupakan salah satu metode untuk melindungi probiotik pada proses pengolahan, penyimpanan dan pada saluran pencernaan yang bersifat asam. Penelitian ini bertujuan untuk mengetahui viabilitas probiotik yang telah ter-enkapsulasi dengan matriks alginat dan kitosan terhadap pengujian dalam simulasi cairan asam lambung. Proses enkapsulasi dilakukan dengan cara mencampurkan Lactobacillus sp. dengan Na-Alginat sehingga membentuk suspensi sebagai bahan enkapsulasi. Mikrokapsul yang terbentuk dilapisi kitosan dengan konsentrasi 1,2\%; 1,6\% dan 2\%. Lactobacillus sp. yang telah terenkapsulasi oleh matriks kitosan diuji viabilitasnya dalam simulasi cairan asam lambung $(\mathrm{NaCl} \mathrm{0,2 \%} \mathrm{pH} \mathrm{1,2} \mathrm{dan} \mathrm{pH} 3)$ selama 1 menit, 60 menit dan 120 menit dengan metode TPC (Total Plate Count). Setelah dilakukan uji viabilitas didapatkan Lactobacillus sp. hasil enkapsulasi dengan penyalut kitosan $2 \%$ dapat mempertahankan viabilitas bakteri Lactobacillus sp. dengan jumlah koloni $\log 7,41 \mathrm{Cfu} / \mathrm{gram}$ pada simulasi cairan asam lambung $\mathrm{pH} 3$ selama 120 menit dan $\log$ 4,78 Cfu/gram pada simulasi cairan asam lambung pH 1,2 selama 120 menit.

Kata kunci: probiotik, enkapsulasi, lactobacillus sp., na-alginat, kitosan
\end{abstract}

\section{Pendahuluan}

Bakteri Asam Laktat (BAL) termasuk ke dalam bakteri gram positif yang tidak menghasilkan spora, memililiki dua bentuk, yaitu bentuk bulat dan batang yang memproduksi asam laktat selama fermentasi karbohidrat sebagai hasil akhir metabolit utama [1]. Streptococcus, Pediococcus, Leuconostoc, dan Lactobacillus merupakan bakteri yang termasuk ke dalam BAL. Bakteri Lactobacillus sp. merupakan strain bakteri asam laktat [2] Lactobacilus sp. tidak dapat bertahan hidup pada tingkat keasaman lambung ( $\mathrm{pH}$ 1,5-2,5) dan selama proses pengolahan pada suhu tinggi [3]. Penambahan zat pembawa agar probiotik berfungsi agar Lactobacillus sp. bisa bertahan hidup saat melewati lambung dan berkoloni di usus [4].

Standar minimum bakteri sediaan probiotik dalam makanan yaitu sebanyak 106-107 CFU (colony forming unit)/gram. Probiotik adalah mikroorganisme hidup yang dapat memberikan manfaat kesehatan apabila dikonsumsi dalam jumlah cukup [5]. Upaya untuk meningkatkan ketahanan hidup Lactobacillus 
sp. dapat melalui metode enkapsulasi dengan cara memberikan perlindungan kepada bakteri. Proses enkapsulasi dilakukan dengan menggunakan bahan polimer alam seperti Na-Alginat dan Kitosan.

Alginat merupakan salah satu biopolimer yang paling umum digunakan dalam enkapsulasi. Keuntungannya adalah tidak toksik, murah, dan membentuk matriks gel untuk menjerap mikroba dengan larutan $\mathrm{CaCl} 2$ [6]. Mikrokapsul Alginat berbentuk pori (porous), maka zat aktif didalamnya dapat mengalami kebocoran (leakage) [7]. Untuk mencegah kebocoran maka ditambahkan kitosan yang berfungsi sebagai penyalut. Kitosan merupakan hasil dari deasetilasi kitin, yang bersumber dari cangkang hewan vertebrata (dalam hal ini rajungan) [8].

Penelitian sebelumnya yang dilakukan oleh [9], tentang preparasi mikrokapsul kompleks alginat/kitosan/karboksimetil kitosan dan aplikasi dalam Lactobacillus casei ATCC 393, pada penelitian tersebut menggunakan kitosan $1 \%$ sebagai bahan pengapsul, variasi $\mathrm{pH}$ simulasi asam lambung yaitu 2,0; 3,0; dan 6,5. Diketahui bahwa kelangsungan hidup sel yang dienkapsulasi secara signifikan lebih baik daripada sel bebas setelah dilakuakn uji simulasi cairan asam lambung $(\mathrm{pH} 2,0)$ dan mikrokapsul alginatkitosan-CMCS dapat melindungi Lactobacillus casei terhadap lingkungan asam secara efektif. Sedangkan penelitian yang dilakukan oleh [10] tentang Mikroenkapsulasi Probiotik dan Prebiotik Dalam Kapsul Alginat-Kitosan untuk Meningkatkan Ketahanan Hidup dalam Simulasi Usus. Dimana pada penelitian tersebut menggunakan kitosan sebagai bahan penyalut dari mikrokapsul alginat. Upaya penyalutan dari mikrokapssul alginat ini dilakuakan karena Lactobacillus gasseri yang terjerap oleh alginat yang telah disalut kitosan mempunyai viabilitas yang lebih baik dibandingkan alginat tanpa penyalutan kitosan. Hal ini terjadi karena kitosan mempunyai gugus amin bebas bermuatan positif sehingga dapat membentuk membran semipermeabel pada sekitar polimer bermuatan negatif seperti alginat. Membran yang terbentuk tidak larut dalam pelarut silang alginat, $\mathrm{CaCl} 2$ sehingga dapat meningkatkan stabilitas gel dan membentuk penghalang pada pelepasan.

Ditinjau dari alasan tersebut, maka perlu dilakukan pembuatan enkapsulasi probiotik Lactobacillus sp. menggunakan dua tahap proses serta viabilitas terhadap viabilitas Lactobacillus sp. dalam simulasi cairan asam lambung. Penelitian ini bertujuan untuk mengetahui viabilitas probiotik yang telah terenkapsulasi dengan matriks alginat dan kitosan terhadap pengujian dalam simulasi cairan asam lambung. Penelitian ini diharapkan dapat memberikan informasi ilmiah mengenai viabilitas probiotik Lactobacillus sp. yang telah terenkapsulasi dengan matriks alginat dan kitosan terhadap pengujian dalam simulasi cairan asam lambung.

\section{Metode Penelitian}

Penelitian ini telah dilaksanakan di Laboratorium Loka Penelitian Teknologi Bersih - Lembaga Ilmu Pengetahuan Indonesia, Bandung dari Bulan Februari sampai Bulan Agustus 2020. Metode yang digunakan pada penelitian ini yaitu eksperimental laboratorium dengan metode Total Plate Count (TPC).

\section{Prosedur Kerja}

\section{Inokulasi bakteri Lactobacillus sp.}

Pada penelitian enkapsulasi probiotik Lactobacillus sp. menggunakan dua tahap proses dimulai dari inokulasi bakteri Lactobacillus sp. Bakteri dibuat suspensi dengan beberapa tahapan sehingga bakteri dapat langsung dilakukan perhitungan koloni bakteri sel bebas menggunakan metode dilusi bertingkat sampai pengenceran $10^{10}$ dan diinkubasi dalam suasana asam lambung pada suhu $37^{\circ} \mathrm{C}$ serta dibuat enkapsulasi shell natrium alginat dan core berisi bakteri dan kemudian beads probiotik dengan shell natrium alginat yang telah terbentuk dalam larutan $\mathrm{CaCl}_{2}$ dimasukkan ke dalam larutan kitosan yang berfungsi sebagai penyalut tambahan [9].

2. Enkapsulasi

Enkapsulasi dilakukan dengan metode ekstrusi menggunakan bahan pengapsul Na-alginat dan Kitosan. Kemudian dilakukkan perhitungan koloni Lactobacillus sp. yang sudah dienkapsulasi dan diinkubasi dalam cairan simulasi asam lambung pH 1,2 dan pH 3 dengan variasi waktu 1 menit, 60 menit, dan 120 menit.

\section{Total Plate Count (TPC)}

Perhitungan koloni bakteri pada suspensi Lactobacillus sp. dilakukan dengan menggunakan metode TPC (Total Plate Count) dimana $1 \mathrm{~mL}$ suspensi Lactobacillus sp. dimasukkan ke dalam $9 \mathrm{~mL}$ larutan Peptone $0,1 \%$ steril, kemudian dihomogenkan dengan vortex, larutan yang telah homogen dipipet sebanyak $1 \mathrm{~mL}$ ke dalam cawan petri steril dan $1 \mathrm{~mL}$ ke dalam $9 \mathrm{~mL}$ larutan Peptone 0,1\% steril sebagai pengenceran selanjutnya. Kemudian $1 \mathrm{~mL}$ larutan homogen yang berada dalam cawan petri ditambahkan dengan media MRS Agar lalu homogenkan sehingga bakteri dapat menyebar dalam cawan petri. Setelah itu cawan petri berisi MRS Agar dan larutan homogen diinkubasi pada suhu $37^{\circ} \mathrm{C}$ selama $48 \mathrm{jam}$. Pada 
perhitungan koloni bakteri ini dilakukan pengenceran dari $10^{1}-10^{9}$ dan didapatkan jumlah koloni bakteri sebanyak $5 \times 10^{10} \mathrm{cfu} / \mathrm{mL}$.

Perhitungan bakteri menggunakan teknik pengujian total bakteri (Total Plate Count) menggunakan media MRS (de Man-Rogasa-Sharpe), diinkubasi selama 48 jam pada suhu $37^{\circ} \mathrm{C}$. Morfologi enkapsulasi probiotik menggunakan pengujian SEM (Scanning Electron Microscophy) serta pengujian total bakteri dapat diketahui perbandingan jumlah koloni bakteri bebas dan bakteri yang dienkapsulasi dan perbandingan asam lambung [9].

4. Uji Organoleptik

Untuk uji organoleptik dilakukan dengan cara melihat bentuk, warna dan bau.

\section{Hasil dan Pembahasan}

Bakteri asam laktat (BAL) merupakan sekelompok bakteri yang dapat memberikan manfaat bagi kesehatan. Lactobacillus sp. merupakan genus terbesar dalam bakteri asam laktat. Lactobacillus sp. merupakan bakteri gram positif, anaerob fakultatif, katalase-negatif, heterofermentatif, batang pembentuk non-spora, dan diisolasi dari banyak habitat. Kultur bakteri Lactobacillus sp. diperoleh dari Loka Penelitian Teknologi Bersih LIPI Bandung.

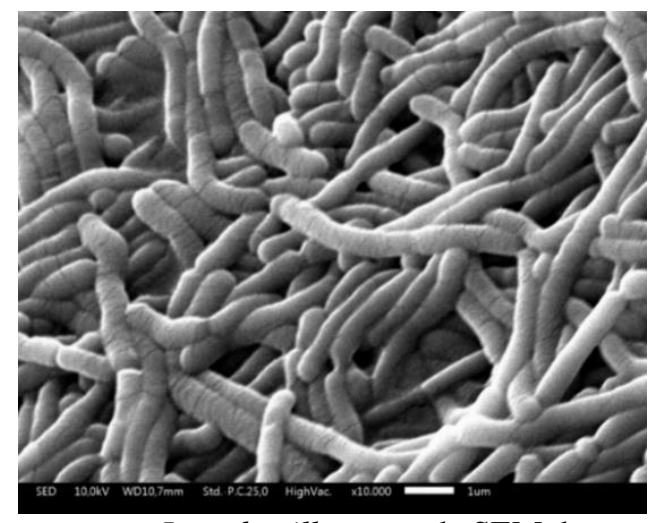

Gambar 1. Hasil pengamatan Lactobacillus $s p$ pada SEM dengan perbesaran $10.000 \mathrm{x}$ Sumber: Loka Penelitian Teknologi Bersih - Lembaga Ilmu Pengetahuan Indonesia, Bandung

Berdasarkan Gambar 1. terlihat bahwa Lactobacillus sp. berbentuk batang dengan lebar 0,7-1,1 $\mu \mathrm{m}$ dan panjang 2.0-4.0 $\mu \mathrm{m}$. Suhu optimum untuk pertumbuhan Lactobacillus adalah pada $30-37^{\circ} \mathrm{C}$. Lactobacillus sp. terdapat dalam flora normal di saluran cerna manusia, saluran kemih, mulut, dan vagina wanita. Lactobacillus merupakan pelindung dalam tubuh namun pada beberapa pasien dengan gangguan imunitas, bakteri ini dapat berubah menjadi patogen. Beberapa jurnal telah mempublikasikan mengenai pasien AIDS (Acquired Immune Deficiency Syndrome), neutropenia, dan pasien yang telah melakukan transplantasi organ mengalami infeksi yang disebabkan oleh Lactobacillus sp. [11]. Lactobacillus sp. diperlukan untuk mempertahankan kesehatan saluran cerna dan tidak dianggap patogen pada tubuh host [4]. Beberapa keuntungannya seperti mengurangi gejala diare, menstabilkan barier mukosa usus, sebagai anti kanker dan mengurangi gejala irritable bowel syndrome. Bakteri ini terdapat dalam yoghurt, keju, atau produk olahan susu lainnya [12]. Diketahui bahwa bakteri probiotik tidak tahan terhadap asam lambung dan untuk meningkatkan ketahanan hidup probiotik saat melewati asam lambung adalah dengan melakukan teknik enkapsulasi. Metode yang dilakukan ini bertujuan untuk memenuhi syarat probiotik yang ditetapkan oleh WHO/FAO (2001) yaitu makanan yang dikonsumsi mengandung probiotik harus mencapai usus dan dapat berkoloni di dalam usus serta mengandung kurang lebih $10^{6}-10^{7} \mathrm{cfu} / \mathrm{g}$ [13].

Metode ekstrusi merupakan metode yang digunakkan dalam pembuatan enkapsulasi Lactobacillus sp. menggunakan matriks kitosan. Enkapsulasi atau sering disebut penyalutan adalah proses pembentukan salut dari suatu partikel untuk mencapai target yang diinginkan, seperti imobilitas atau isolasi perlindungan atau stabilisasi, pelepasan terkontrol, dan perubahan sifat fisik [14]. Enkapsulasi probiotik telah diteliti sebelumnya yang bertujuan untuk meningkatkan kelangsungan hidup probiotik dalam produk makanan dan saluran pencernaan [15]. Enkapsulasi bertujuan untuk menstabilkan sel yang berpotensi untuk meningkatkan kelangsungan dan stabilitas probiotik selama produksi, penyimpanan, dan penanganan [11]. Bakteri probiotik yang dienkapsulasi dapat meningkatkan viabilitasnya dibandingkan dengan sel bebas tanpa enkapsulasi [16].

Pada proses enkapsulasi metode yang digunakan adalah metode ekstrusi dan metode gelasi ionik. Pemilihan metode ekstrusi bertujuan untuk menghindari suhu ekstrim saat proses enkapsulasi yang dapat 
mengakibatkan kurangnya jumlah ataupun viabilitas bakteri. Alasan pemilihan metode ekstrusi yaitu karena selain alat yang digunakkan sederhana (jarum suntik), metode ekstrusi juga dapat menghindari kerusakan yang diakibatkan oleh suhu tinggi dan tekanan yang ekstrim pada metode spray drying [17]. Sementara itu, metode gelasi ionik dipilih karena prosesnya yang sederhana, tidak menggunkan pelarut organik, dan dapat dikontrol dengan mudah [18].

Proses yang dilakukan pada metode ekstrusi yaitu larutan Natrium Alginat yang telah disiapkan kemudian ditambahkan suspensi bakteri selanjutnya campuran tersebut di masukkan ke dalam syringe lalu dengan menggunakan jarum dan bantuan pump sehingga campuran jatuh ke dalam larutan $\mathrm{CaCl}_{2}$ yang berfungsi sebagai larutan pengeras/pembentuk gel [19]. Setelah mikrokapsul jatuh ke dalam larutan pengeras, mikrokapsul direndam di dalamnya dan diaduk selama 30 menit, setelah itu mikrokapsul disaring dengan menggunakan kertas saring Whatman No.40 didalam Lmainar Air Flow (LAF) secara aseptik, setelah mikrokapsul tersaring kemudian dibilas mikrokapsul menggunakan aquadest steril. Hal ini bertujuan agar mikrokapsul tidak melekat satu sama lain kemudian mikrokapsul ditimbang untuk mengetahui dari penyalutan matrik kitosan pada tahap berikutnya. Mikrokapsul yang telah ditimbang kemudian dimasukkan ke dalam wadah berisi kitosan kemudian mulut wadah tersebut ditutup dengan Aluminium foil dan diaduk selama 15 menit. Apabila proses penyalutan dengan kitosan telah selesai kemudian mikrokapsul disaring dan dibilas kembali menggunakan aquadest steril lalu ditimbang untuk memperoleh berat akhir dari proses penyalutan tersebut.

Pengaruh penyalutan dua jenis penyalutan (enkapsulasi) pada bakteri probiotik lebih mampu mempertahankan bakteri probiotik dibandingkan bakteri yang tidak disalut oleh penyalut kitosan [20]. Terdapat beberapa faktor yang dapat mempengaruhi keberhasilan proses enkapsulasi seperti sifat fisiko kimia bahan inti dan bahan penyalut, serta tahapan dalam enkapsulasi [21]. Syarat bahan penyalut yang digunakan untuk enkapsulasi harus dapat memberikan suatu lapisan tipis yang melekat dengan bahan inti, dapat bercampur secara kimia dan tidak bereaksi dengan bahan inti. Proses enkapsulasi dilakukan terhadap bakteri kandidat probiotik berlapis kitosan menggunakan alginat. Alasan menggunakan kedua bahan tersebut karena alginat termasuk hidrokoloid alami, telah dilaporkan pada beberapa penelitian bahwa enkapsulasi menggunakan alginat dapat mempertahankan viabilitas probiotik dalam produk makanan asam selama proses penyimpanan dengan suhu dingin [22]. Sedangkan pemilihan kitosan dikarenakan biopolimer alami yang ketersediaan di alam sangat melimpah, selain itu kitosan merupakan polisakarida yang dihasilkan dari deasetilasi kitin [23]. Beberapa keuntungan dari penggunaan kitosan seperti antimikroba, sukar larut dalam air, murah, dan sering digunakan sebagai penyalut beads untuk meningkatkan stabilitasnya [24]. Enkapsulasi Lactobacillus sp. yang telah dihasilkan kemudian dimasukkan ke dalam plastik zipper dan di dalam lemari pendingin dengan suhu $4^{\circ} \mathrm{C}$ dengan tujuan suhu yang rendah dapat menurunkan reaksi kimia yang merugikan [25].

Tabel 1. Hasil uji organoleptik enkapsulasi lactobacillus sp. menggunakan matriks kitosan

\begin{tabular}{cccc}
\hline Konsentrasi & \multicolumn{3}{c}{ Organoleptis } \\
\cline { 2 - 4 } Kitosan & Bentuk & Warna & Bau \\
\hline $1,2 \%$ & Bulat sempurna & Putih & Tidak berbau \\
$1,6 \%$ & Bulat sempurna & Putih & Tidak berbau \\
$2 \%$ & Bulat sempurna & Putih & Tidak berbau \\
\hline
\end{tabular}

Sumber: Loka Penelitian Teknologi Bersih - Lembaga Ilmu Pengetahuan Indonesia, Bandung

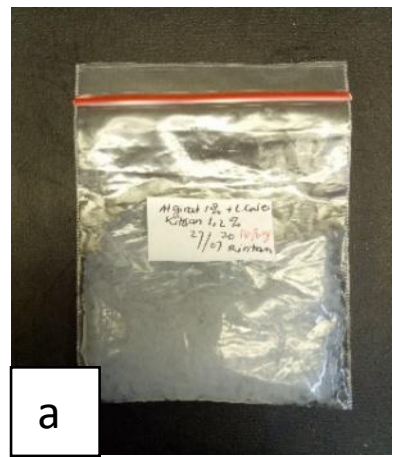

(i)

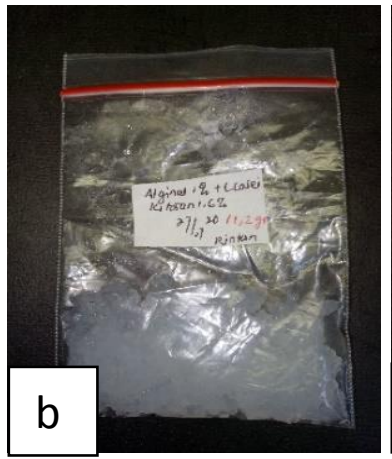

(ii)

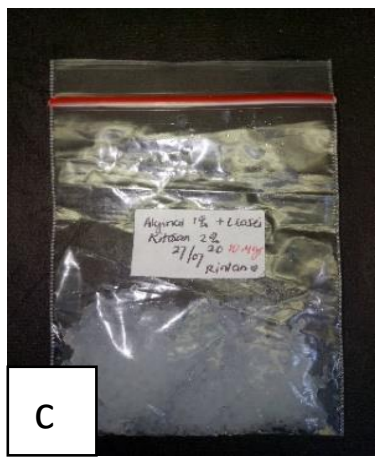

(iii)

Gambar 2. Enkapsulasi Lactobacillus sp. menggunakan matriks kitosan: (a) 1,2\%; (b) 1,6\%; dan (c) $2 \%$. Sumber: Loka Penelitian Teknologi Bersih - Lembaga Ilmu Pengetahuan Indonesia, Bandung 
Berdasarkan Tabel 1 dan Gambar 2 dapat diketahui bahwa uji organoleptik dari enkapsulasi Lactobacillus sp. yang dihasilkan dari ketiga konsentrasi kitosan $(1,2 \% ; 1,6 \%$; dan $2 \%)$ memiliki bentuk bulat dengan permukaan yang lembut dan halus ketika diraba oleh tangan, berwarna putih, dan tidak berbau. Karakteristik dari mikrokapsul yang dihasilkan ditentukan oleh jenis dan komposisi biopolimer yang digunakan dalam proses enkapsulasi akan mempengaruhi diameter dan bentuk mikrokapsul yang dihasilkan. Selain itu, komposisi biopolimer juga akan mempengaruhi viabilitas probiotik yang dienkapsulasi [26] (Sandoval-Castilla O). Pada studi Swelling menunjukkan bahwa mikrokapsul alginat dan kitosan dengan daya swelling yang rendah tidak terjadi pengikisan pada media lambung yang disimulasikan. Hal tersebut terjadi karena terkait adanya ionisasi polielektrolit antara alginat dan kitosan. Pada tingkat keasaman mendekati $\mathrm{pH} \mathrm{1,} \mathrm{kitosan} \mathrm{terprotonasi,} \mathrm{gugus} \mathrm{aminonya} \mathrm{tetap} \mathrm{sebagai} \mathrm{NH}^{3+}$, dan alginat memiliki gugus karboksilat yang tidak terionisasi, sebagai COO- dan menunjukkan kecenderungan mengendap. Sifat ini yang dapat menyebabkan struktur menjadi tertutup, menghasilkan kontrol yang lebih kuat pada pelepasan obat dalam media asam [27].

Uji viabilitas Lactobacillus sp. hasil enkapsulasi bertujuan untuk mengetahui keberhasilan dari pembuatan enkapsulasi Lactobacillus sp. menggunakan matriks kitosan dengan menggunakna metode TPC (Total Plate Count). Metode TPC (Totral Plate Count) merupakan metode yang digunakan untuk menghitung jumlah bakteri pada sampel yang akan dilakukan pengujian. Jumlah mikroorganisme pada sampel yang diperoleh dengan metode ini adalah gambaran populasi, karena tidak semua mikroorganisme dapat tumbuh dalam media MRS Agar dan kondisi inkubasi yang diterapkan [28]. Hasil perhitungan Lactobacillus sp dapat dilihat pada Tabel 2.

Tabel 2. Perhitungan Lactobacillus sp. Hasil Enkapsulasi Matriks Kitosan

\begin{tabular}{ccc}
\hline $\begin{array}{c}\text { Konsentrasi } \\
\text { Kitosan }\end{array}$ & $\begin{array}{c}\text { Free call Lactobacillus sp. } \\
(\mathrm{cfu} / \mathrm{mL})\end{array}$ & $\begin{array}{c}\text { Lactobacillus sp. } \\
\text { Hasil Enkapsulasi }(\mathrm{cfu} / \mathrm{g})\end{array}$ \\
\hline $1,2 \%$ & $5 \times 10^{10}$ & $0,6 \times 10^{8}$ \\
$1,6 \%$ & $5 \times 10^{10}$ & $1,6 \times 10^{8}$ \\
$2 \%$ & $5 \times 10^{10}$ & $3,3 \times 10^{8}$ \\
\hline
\end{tabular}

Sumber: Loka Penelitian Teknologi Bersih - Lembaga Ilmu Pengetahuan Indonesia, Bandung

Berdasarkan Tabel 2 terlihat bahwa hasil perhitungan jumlah koloni bakteri setelah dienkapsulasi, yaitu berturut-turut dari konsentrasi $1,2 \% ; 1,6 \%$; dan $2 \%$ adalah $0,6 \times 10^{8} \mathrm{cfu} / \mathrm{g} ; 1,6 \times 10^{9} \mathrm{cfu} / \mathrm{g}$; dan 3,3 x $10^{8} \mathrm{cfu} / \mathrm{g}$. Hal ini menunjukkan bahwa tidak terjadi penurunan jumlah koloni yang signifikan antara suspensi bakteri bebas dengan mikrokapsul hasil enkapsulasi menggunakan matriks kitosan, sehingga mikrokapsul daapat diuji viabilitas dan survivabilitas pada kondisi lingkungan yang ekstrim yaitu simulasi cairan asam lambung ( $\mathrm{NaCl} 0,2 \% \mathrm{pH} 1,2$ dan 3) dengan waktu inkubasi selama 1 menit, 60 menit, dan 120 menit. Jumlah koloni bakteri awal sebelum dilakukan enkapsulasi adalah $5 \times 10^{10} \mathrm{cfu} / \mathrm{mL}$ untuk seluruh perlakuan konsentrasi kitosan $(1,2 \% ; 1,6 \%$; dan $2 \%)$.

Enkapsulasi adalah salah satu metode yang dapat digunakan untuk meningkatkan viabilitas bakteri probiotik. Merujuk pada D'Orazio, (2015) [29] jumlah bakteri dihitung menggunakan metode TPC (Total Plate Count). Jumlah koloni yang diperoleh dinyatakan dengan CFU (Coloning Forming Unit) [27]. Buffered Peptone Water (BPW) 0,1\% merupakan larutan pengencer yang berfungsi untuk mengencerkan media. Natrium sitrat $1 \%$ merupakan larutan simulasi usus yang berfungsi membuka penyalutan bakteri, sehingga dapat dibuktikan apakah dengan adanya penyalutan dapat memperlambat dan atau mempertahankan jumlah koloni bakteri yang seharusnya tetap saat berada dalam kondisi ekstrim.

Tabel 2 juga menunjukkan penggunaan suspensi bakteri untuk enkapsulasi Lactobacillus sp. dengan matriks kitosan berbeda. Hal ini dikarenakan kendala teknis dalam pembuatan mikrokapsul dan juga umur simpan suspensi bakteri bebas tidak dapat bertahan lama meskipun disimpan didalam lemari pendingin dengan suhu $4^{\circ} \mathrm{C}$. Jumlah bakteri dari free cell yang digunakan dalam proses enkapsulasi akan sangat mempengaruhi jumlah bakteri awal yang digunakan, maka akan terserap ke dalam polimer. Sehingga viabilitas bakteri setelah proses enkapsulasi akan tetap terjaga dan bakteri tersebut dapat memberikan manfaat bagi kesehatan, yaitu antara $10^{6}-10^{8} \mathrm{cfu} / \mathrm{mL}[13]$.

Ketika probiotik berhasil terenkapsulasi, penting untuk mengamatinya pada dua kondisi yaitu pada cairan lambung dan usus halus simulasi. Sebagian besar penelitian in vitro mengenai viabilitas probiotik terenkapsulasi menyarankan menggunakan Buffered Peptone Water (BPW) sebagai sumber makanan yang dapat mempertahankan integritas dan viabilitas sel [11]. Sementara untuk $\mathrm{pH}$ menggunakan larutan Natrium Klorida $(\mathrm{NaCl})$ diatur pada kondisi $1-3$, nilai ini merupakan kisaran $\mathrm{pH}$ yang umumnya diamati pada lambung manusia [30]. 
Pengujian viabilitas mikrokapsul untuk hasil enkapsulasi dengan matriks kitosan dalam simulasi cairan asam lambung dan usus halus dilakukan variasi terhadap waktu dan konsentrasi cairan asam lambung. Waktu inkubasi mikrokapsul di dalam simulasi cairan asam lambung berlangsung selama 1 menit, 60 menit, dan 120 menit, sedangkan konsentrasi simulasi cairan asam lambung yang digunakan yaitu pada derajat keasaman $\mathrm{pH}$ 1,2 dan 3. Setelah mikrokapsul melalui proses inkubasi selama 1 menit, 60 menit dan 120 menit pada larutan simulasi yang telah ditentukan, kemudian mikrokapsul direndam kembali dalam simulasi larutan garam empedu sambil diaduk sampai mikrokapsul hancur, selanjutnya disuspensikan ke dalam larutan peptone $0,1 \%$ dan dilakukan pengenceran bertingkat untuk dihitung jumlah koloni bakteri dengan metode TPC (Total Plate Count) [29]. Setelah dilakukan pengujian didapatkan hasil bahwa mikrokapsul hanya bisa tumbuh stabil dalam simulasi cairan asam lambung $\mathrm{pH} 3$, sedangkan pada $\mathrm{pH}$ 1,2 terjadi penurunan pertumbuhan seperti yang terlihat pada Tabel 3 dan Tabel 4.

Tabel 3. Jumlah koloni bakteri pada free cell dan koloni bakteri setelah proses enkapsulasi dengan variasi waktu inkubasi dalam simulasi cairan asam lambung $\mathrm{pH} 3$

\begin{tabular}{ccccccc}
\hline \multirow{3}{*}{$\begin{array}{c}\text { Konsentrasi } \\
\text { Kitosan }\end{array}$} & \multicolumn{3}{c}{ Free cell } & \multicolumn{3}{c}{ Mikrokapsul } \\
\cline { 2 - 6 } & $1^{\prime}$ & $60^{\prime}$ & $120^{\prime}$ & 1 & $60^{\prime}$ & $120^{\prime}$ \\
& $\mathrm{Cfu} / \mathrm{mL}$ & $\mathrm{Cfu} / \mathrm{mL}$ & $\mathrm{Cfu} / \mathrm{mL}$ & $\mathrm{Cfu} / \mathrm{gr}$ & $\mathrm{Cfu} / \mathrm{gr}$ & $\mathrm{Cfu} / \mathrm{gr}$ \\
\hline $1,2 \%$ & $7 \times 10^{8}$ & $2 \times 10^{5}$ & $2 \times 10^{4}$ & $1 \times 10^{8}$ & $5 \times 10^{7}$ & $4,3 \times 10^{3}$ \\
$1,6 \%$ & $7 \times 10^{8}$ & $2 \times 10^{5}$ & $2 \times 10^{4}$ & $2 \times 10^{8}$ & $24 \times 10^{7}$ & $5,3 \times 10^{5}$ \\
$2 \%$ & $7 \times 10^{8}$ & $2 \times 10^{5}$ & $2 \times 10^{4}$ & $3 \times 10^{8}$ & $24 \times 10^{7}$ & $26 \times 10^{6}$ \\
\hline
\end{tabular}

Sumber: Loka Penelitian Teknologi Bersih - Lembaga Ilmu Pengetahuan Indonesia, Bandung

Tabel 4. Jumlah koloni bakteri pada free cell dan koloni bakteri setelah proses enkapsulasi dengan variasi waktu inkubasi dalam simulasi cairan asam lambung $\mathrm{pH} 1,2$

\begin{tabular}{ccccccc}
\hline & \multicolumn{9}{c}{$\mathrm{pH} 1,2$} \\
\hline \multirow{2}{*}{$\begin{array}{c}\text { Konsentrasi } \\
\text { Kitosan }\end{array}$} & $1^{\prime}$ & $60^{\prime}$ & $120^{\prime}$ & $1^{\prime}$ & $60^{\prime}$ & $120^{\prime}$ \\
\cline { 2 - 7 } & $\mathrm{Cfu} / \mathrm{mL}$ & $\mathrm{Cfu} / \mathrm{mL}$ & $\mathrm{Cfu} / \mathrm{mL}$ & $\mathrm{Cfu} / \mathrm{gr}$ & $\mathrm{Cfu} / \mathrm{gr}$ & $\mathrm{Cfu} / \mathrm{gr}$ \\
\hline $1,2 \%$ & 0 & 0 & 0 & $6 \times 10^{7}$ & 0 & 0 \\
$1,6 \%$ & 0 & 0 & 0 & $4 \times 10^{7}$ & $3,6 \times 10^{3}$ & 0 \\
$2 \%$ & 0 & 0 & 0 & $1 \times 10^{7}$ & $2,6 \times 10^{5}$ & $0,6 \times 10^{5}$ \\
\hline
\end{tabular}

Sumber: Loka Penelitian Teknologi Bersih - Lembaga Ilmu Pengetahuan Indonesia, Bandung

Berdasarkan Tabel 3 bakteri Lactobacillus sp. terenkapsulasi cenderung memiliki ketahanan yang lebih baik dibandungkan dengan free cell setelah dilakuakan uji pada simulasi cairan asam lambung $\mathrm{pH} 3$ dengan nilai awal koloni berturut-turut dengan lama inkubasi 1 menit, 60 menit, 120 menit 7 x $10^{8}$ $\mathrm{cfu} / \mathrm{mL}, 2 \times 10^{5} \mathrm{cfu} / \mathrm{mL}$ dan $2 \times 10^{4} \mathrm{cfu} / \mathrm{mL}$, sedangkan untuk simulasi cairan asam lambung $\mathrm{pH} 1,2 \mathrm{pada}$ Tabel 4 dengan lama inkubasi 1 menit, 60 menit dan 120 menit tidak terjadi pertumbuhan koloni pada free cell. Hal ini disebabkan bakteri Lactobacillus sp. tidak tahan terhadap kondisi ekstrim. Lamanya waktu inkubasi yang dilakukan dalam simulasi cairan asam lambung $\mathrm{pH} 3$ dan pada simulasi cairan asam lambung $\mathrm{pH} 1,2$ terjadi penurunan yang sangat signifikan untuk mikrokapsul yang tersalut oleh kitosan dengan konsentrasi $1,2 \%$ dan 1,6\%, sedangkan untuk penyalutan kitosan konsentrasi $2 \%$ dapat bertahan hidup dengan inkubasi selama 120 menit dengan jumlah $0,6 \times 10^{5} \mathrm{cfu} / \mathrm{gram}$. Sehingga dapat diasumsikan bahwa probiotik yang terenkapsulasi berada dalam range standar yang telah ditentukan oleh $\mathrm{FAO} / \mathrm{WHO}$, 2001 nilai minimum yang harus dipenuhi sekitar $10^{6}-10^{7} \mathrm{Cfu} /$ gram bakteri dalam sediaan probiotik [5]. Hal tersebut sesuai dengan bahwa enkapsulasi bertujuan untuk melindungi bakteri dari faktor-faktor berbahaya bagi bakteri [10].

Semakin besar persentase dan berat molekul kitosan yang digunakan untuk mengenkapsulasi probiotik semakin lambat proses pelepasan sel bakteri seperti yang terlihat pada Tabel $\mathbf{3}$ bahwa jumlah bakteri Lactobacillus sp. hasil enkapsulasi yang memliki ketahanan optimum adalah penyalutan menggunakan matriks kitosan dengan konsentrasi $2 \%$ mengalami penurunan yang sangat kecil dalam waktu inkubasi 1 menit, 60 menit dan 120 menit berturut-turut dengan nilai $3 \times 10^{8} \mathrm{cfu} / \mathrm{g} ; 24 \times 10^{7} \mathrm{cfu} / \mathrm{g}$; dan $26 \times 10^{6}$ dalam simulasi cairan asam lambung pH 3. Hal ini sesuai dengan teori tersebut [31]

Probiotik yang masuk ke dalam saluran cerna akan mengalami penurunan jumlah yang disebabkan oleh paparan pada tingkat keasaman yang tinggi, garam empedu, enzim dan pergerakan saluran cerna. Hasil dari proses enkapsulasi dapat dikatakan berhasil apabila bahan yang dienkapsulasi memiliki viabilitas sel yang relatif tinggi dan memiliki sifat-sifat fisiologis yang relatif sama sebelum dienkapsulasi 
[32]. Bakteri Lactobacillus sp. yang telah terenkapsulasi kemudian dilakukan uji simulasi cairan asam lambung pada $\mathrm{pH} 3$ dapat meningkatkan survivabilitas bakteri Lactobacillus sp., grafik \% survivabilitas dan viabilitas (log cfu). Semakin lama waktu inkubasi berpengaruh pada penurunan survivabilitas Lactobacillus sp. menurut [33]. Mikroenkapsulasi probiotik yang dienkapsulasi menggunakan alginat dan penyalutan kitosan dapat meningkatkan viabilitas Lactobacillus sp. dan B.bifidium pada kondisi cairan gastrointestinal, hasil penelitian menunjukkan hal yang sama dengan teori tersebut.

Enkapsulasi probiotik terbukti dapat mempertahankan viabilitas probiotik, dengan cara melindungi sel probiotik dari kondisi yang merugikan kemudian mengurangi penurunan jumlah probiotik [34]. Bakteri probiotik yang jumlahnya diatas $10^{7} \mathrm{cfu} / \mathrm{mL}$ memiliki efek menguntungkan bagi kesehatan manusia diantaranya dapat meningkatkan ketahanan tubuh terhadap penyakit terutama infeksi usus dan diare, meningkatkan imunitas tubuh dalam proses pencernaan, dan juga dapat mencegah kanker usus besar [35]. Mikroba seperti probiotik sangat diperlukan dalam saluran cerna, hal ini dikarenakan proses fermentasi yang disebabkan adanya mikroba ini melibatkan vitamin $\mathrm{K}$ dan biotin [36].

Uji foto SEM (Scanning Electron Microscophy) dilakukan untuk mengetahui bentuk morfologi dari bakteri Lactobacillus sp hasil enkapsulasi sebagai kontrol yang kemudian dibandingkan dengan bakteri Lactobacillus $s p$ hasil enkapsulasi yang telah direndam dalam simulasi cairan asam lambung pada $\mathrm{pH}$ 1,2 dan 3 dengan waktu inkubasi 1 menit, 60 menit dan 120 menit. Uji foto SEM dilakukan pada konsentrasi kitosan $2 \%$ yang merupakan konsentrasi yang dapat mempertahankan bakteri karena penurunan viabilitas yang terjadi sangat sedikit.
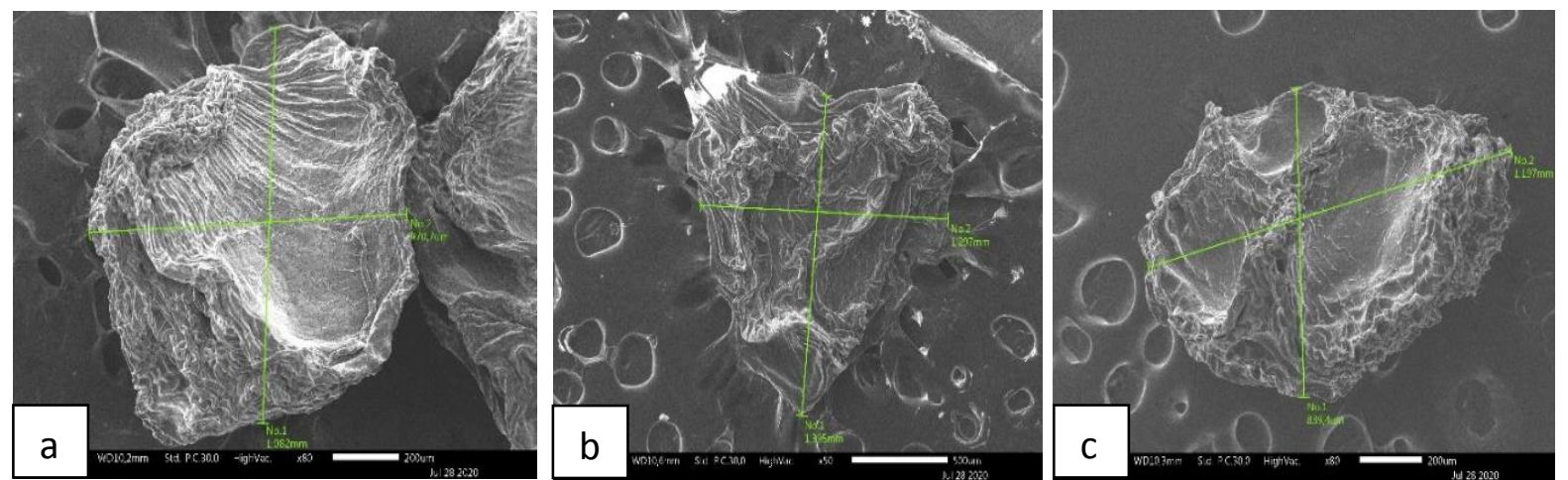

Gambar 3. Uji foto SEM mikrokapsul hasil enkapsulasi pada perbesaran 50x dan 80x: (a) Mikrokapsul Tanpa Diinkubasi dalam Simulasi Cairan Asam Lambung; (b)Mikrokapsul Diinkubasi selama 120 menit dalam Simulasi Cairan Asam Lambung pH 3; (c)Mikrokapsul Diinkubasi selama 120 menit dalam Simulasi Cairan Asam Lambung pH 1,2. Sumber: Loka Penelitian Teknologi Bersih - Lembaga Ilmu Pengetahuan Indonesia, Bandung

Berdasarkan Gambar 3 dari hasil analisa SEM dapat diketahui bahwa ukuran partikel mikrokapsul Lactobacillus sp. dengan konsentrasi kitosan 2\% memiliki ukuran yang berbeda-beda, dimana diameter untuk setiap manik yang diambil secara acak berukuran $839,4 \mu \mathrm{m}$ sampai $1,395 \mu \mathrm{m}$ jika diamati pada perbesaran 50x dan 80x. Besar kecilnya ukuran diameter enkapsulasi berpengaruh pada kemampuan matrik melindungi bakteri yang berada didalamnya. Ukuran enkapsulasi yang lebih besar (2-4 $\mathrm{mm})$ dengan teknik ekstrusi dapat melindungi bakteri Lactobacillus reuteri dibandingkan dengan ukuran enkapsulasi 20-1000 $\mu \mathrm{m}$ [29].
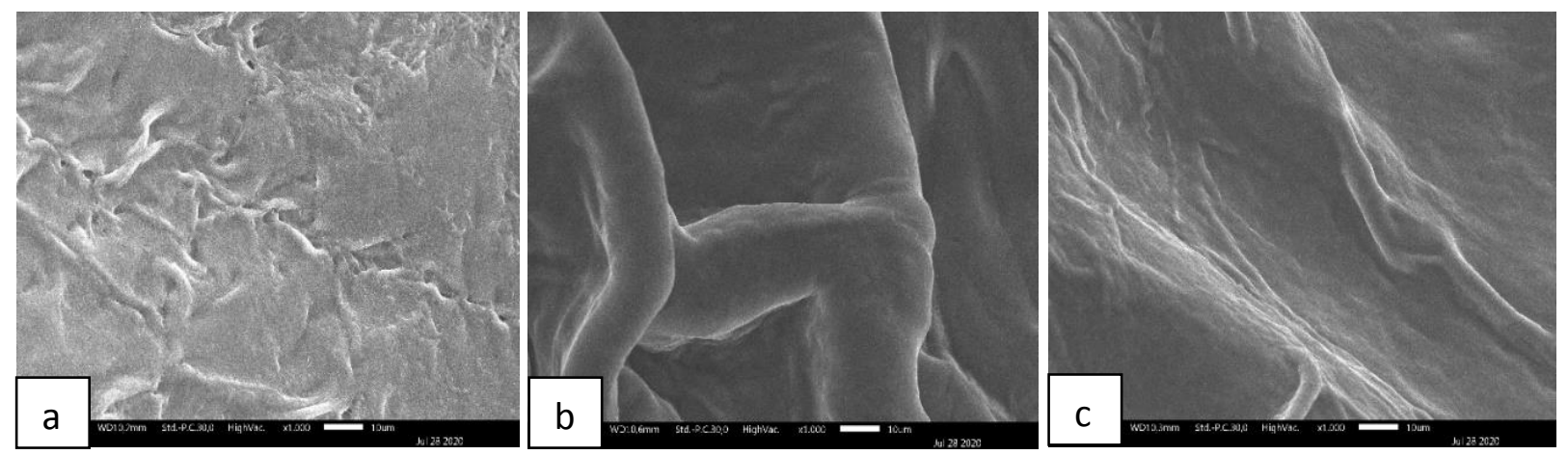

Gambar 4. Uji foto SEM mikrokapsul hasil enkapsulasi pada perbesaran 1000x: (a) Mikrokapsul Tanpa Diinkubasi dalam Simulasi Cairan Asam Lambung; (b) Mikrokapsul Diinkubasi selama 120 menit dalam Simulasi Cairan Asam

Lambung pH 3, (c) Mikrokapsul Diinkubasi selama 120 menit dalam Simulasi Cairan Asam Lambung pH 1,2 Sumber: Loka Penelitian Teknologi Bersih - Lembaga Ilmu Pengetahuan Indonesia, Bandung 
Pada perbesaran 1000x dari hasil analisa SEM terlihat bahwa bahan pengapsul (alginat dan kitosan) mengalami pengerutan yang disebabkan oleh simulasi cairan asam lambung, sehingga muncul ikatan hidrogen yang lebih kuat dan struktur dari bahan pengapsul menjadi rapat. Pada Gambar 4 (a) terdapat rongga dan serat-serat kasar diantara lapisan-lapisannya, sedangkan Gambar 4 (b), dan Gambar 4 (c) terlihat lapisan-lapisan tersebut menjadi lebih rapat.
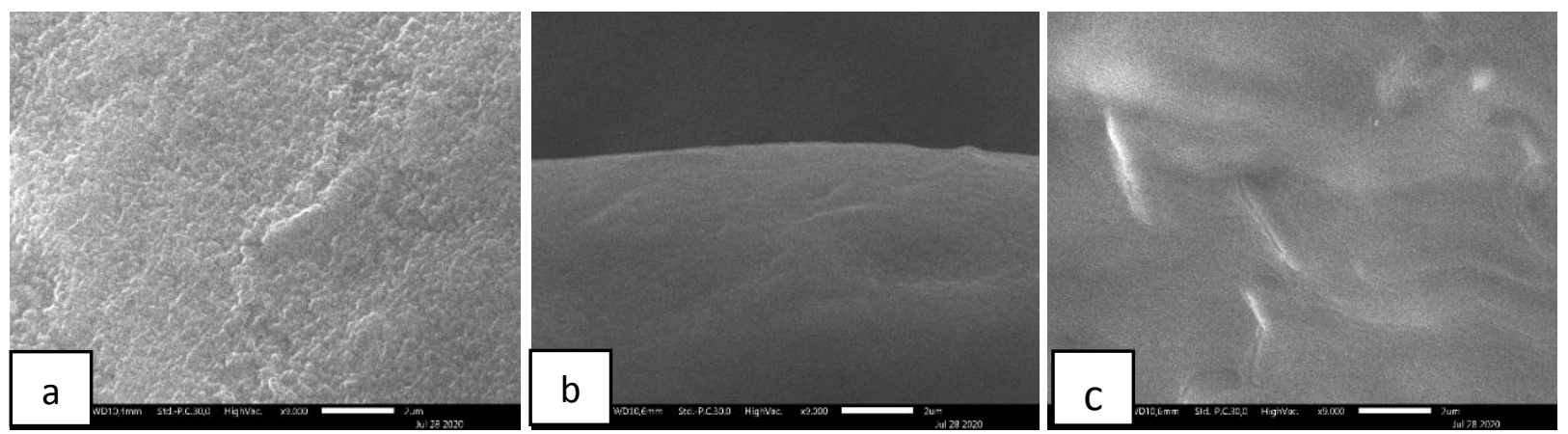

Gambar 5. Uji foto SEM mikrokapsul hasil enkapsulasi pada perbesaran 9000x : (a) Mikrokapsul Tanpa Diinkubasi dalam Simulasi Cairan Asam Lambung; (b)Mikrokapsul Diinkubasi selama 120 menit dalam Simulasi Cairan Asam Lambung pH 3; (c) Mikrokapsul Diinkubasi selama 120 menit dalam Simulasi Cairan Asam Lambung pH 1,2. Sumber: Loka Penelitian Teknologi Bersih - Lembaga Ilmu Pengetahuan Indonesia, Bandung

Pada perbesaran 9000x hasil analisa SEM seperti terlihat pada Gambar 5 terlihat bentuk dari bakteri Lactobacillus sp. yang terlindungi oleh bahan penyalut yaitu kitosan. Pada Gambar 5 (a) terlihat bentuk dari Lactobacillus sp. dengan bentuk batang, Gambar 5 (b) terlihat koloni bakteri Lactobacillus sp. yang terlapisi kitosan dan pada Gambar 5 (c) terlihat bahwa bakteri Lactobacillus sp. sudah tidak terlindungi lagi oleh bahan penyalut. Hal ini sesuai dengan uji viabilitas bakteri hasil enkapsulasi pada simulasi cairan asam lambung dengan $\mathrm{pH}$ 1,2 bahwa tidak didapati pertumbuhan koloni bakteri pada media MRS Agar karena bakteri sudah dalam keadaan bebas tidak ada lapisan yang melindunginya dari paparan kondisi ekstrim.

Sampel diuji menggunakan SEM (Scanning Electron Microscopy) diharuskan dalam keadaan konduktif agar berkas sinar elektron yang ditembakkan dapat diserap oleh sampel dimana sinar elektron akan terhubung dengan amplifier yang menghasilkan gambar pada monitor. Sedangkan manik hasil enkapsulasi bersifat non konduktif sehingga harus dilakukan coating menggunakan emas murni 99,9\% untuk mencapai keadaan konduktif. Pada saat uji SEM kondisi ruang didalamnya harus dalam keadaan vakum sehingga elektron dapat bergerak bebas dan menghasilkan gambar yang jelas pada monitor.

\section{Kesimpulan}

Kitosan dengan konsentrasi 1,2\%; 1,6\%; dan 2\% efektif dapat digunakan sebagai matriks dalam proses enkapsulasi bakteri Lactobacillus sp dengan nilai viabilitas masing-masing $0,6 \times 10^{8} \mathrm{cfu} / \mathrm{g} ; 1,6 \times 10^{8}$ $\mathrm{cfu} / \mathrm{g}$; dan $3,3 \times 10^{8} \mathrm{cfu} / \mathrm{g}$. Setelah dilakukan uji viabilitas probiotik terenkapsulasi dalam simulasi cairan asam lambung pH 1,2 dan 3 dengan waktu inkubasi 1 menit, 60 menit dan 120 menit, didapati konsentrasi penyalut yang dapat mempertahankan viabilitas dalam enkapsulasi adalah kitosan $2 \%$ dengan nilai viabilitas berturut-turut $1 \times 10^{6} \mathrm{cfu} / \mathrm{g} ; 2 \times 10^{5} \mathrm{cfu} / \mathrm{g} ; 0,6 \times 10^{5} \mathrm{cfu} / \mathrm{g}$; dan $3 \times 10^{8} \mathrm{cfu} / \mathrm{g} ; 24 \times 10^{7} \mathrm{cfu} / \mathrm{g} ; 26$ x $10^{6} \mathrm{cfu} / \mathrm{g}$. Semakin lama waktu inkubasi akan mengurangi viabilitas bakteri Lactobacillus sp. Pada uji viabilitas bakteri terenkapsulasi dalam simulasi cairan asam lambung $\mathrm{pH}$ 1,2 probiotik Lactobacillus $\mathrm{sp}$ masih bertahan hidup dengan waktu inkubasi 120 menit.

Hasil yang diperoleh dari uji foto SEM mikrokapsul pada konsentrasi kitosan 2\% tanpa diinkubasi dalam simulasi cairan asam lambung dan diinkubasi selama 120 menit dalam Simulasi Cairan Asam Lambung $\mathrm{pH}$ 1,2 dan $\mathrm{pH} 3$ diameter untuk setiap manik yang diambil secara acak berukuran 839,4 $\mu \mathrm{m}$ sampai $1,395 \mu \mathrm{m}$ jika diamati pada perbesaran 50x dan 80x. Semakin asam kondisi lingkungan maka semakin rapat pula lapisan-lapisan bahan pengapsul yang digunakan, sehingga dapat mendorong bakteri keluar dari manik seperti yang terjadi pada simulasi cairan asam lambung $\mathrm{pH}$ 1,2 dengan waktu inkubasi 120 menit.

\section{Saran}

Dilakukan penelitian lebih lanjut mengenai alat yang dapat digunakan dalam teknik ekstrusi sehingga didapatkan bentuk manik yang lebih seragam. Perlu adanya penelitian lebih lanjut mengenai 
ketahanan bakteri dalam cairan simulasi asam lambung dan usus halus untuk melihat ketahanan bakteri tersebut dalam kondisi yang lebih mirip dengan kondisi saluran pencernaan.

\section{Referensi}

[1] Pato U. Potensi Bakteri Asam Laktat yang Diisolasi dari Dadih untuk Menurunkan Resiko Penyakit Kanker. Potensi Bakteri Asam Laktat yang Diisolasi dari Dadih untuk Menurunkan Resiko Penyakit Kanker. 2017; 24(1):1-8.

[2] Kechagia, M., Basoulis, D., Konstantopoulou, S., Dimitriadi, D., Gyftopoulou, K., Skarmoutsou, N., \& Fakiri, E. M. (2013). Health Benefits of Probiotics: A Review. ISRN Nutrition, 2013, 17. doi:10.5402/2013/481651

[3] Osman Gul and Muhammet Dervisoglu. (2020). European Food Science and Engineering. Optimization of spray drying conditions for microencapsulation of Lactobacillus casei Shirota using response surface methodology. 1 (1), 1-8 https://dergipark.org.tr/tr/pub/efse

[4] Del Piano M, Carmagnola S, Ballarè M, Sartori M, Orsello M, Balzarini M, et al. Is microencapsulation the future of probiotic preparations? the increased efficacy of gastro-protected probiotics. Gut Microbes. 2011;2(2):120-3.

[5] Setijawati D, Firdaus M, Kartikaningsih K. The Effect of Lactobacillus Acidophilus Microcapsule Which Encapsulated by Kappa Caragenan Toward in Vivo Functional Test. Res J Life Sci. 2014;1(1):27-36.

[6] Cook MT, Tzortzis G, Khutoryanskiy V V., Charalampopoulos D. Layer-by-layer coating of alginate matrices with chitosan-alginate for the improved survival and targeted delivery of probiotic bacteria after oral administration. J Mater Chem B. 2013;1(1):52-60.

[7] Westman, J. O., Ylitervo, P., Franzén, C. J., \& Taherzadeh, M. J. (2012). Effects of encapsulation of microorganisms on product formation during microbial fermentations. Applied Microbiology and Biotechnology, 96(6), 1441-1454. doi:10.1007/s00253-012-4517-y

[8] Praveen, R., Prasad Verma, P. R., Venkatesan, J., Yoon, D.-H., Kim, S.-K., \& Singh, S. K. (2017). In vitro and in vivo evaluation of gastro-retentive carvedilol loaded chitosan beads using Gastroplus $^{\mathrm{TM}}$. International Journal of Biological Macromolecules, 102, 642650. doi:10.1016/j.ijbiomac.2017.04.067

[9] Li XY, Chen XG, Sun ZW, Park HJ, Cha DS. Preparation of alginate/chitosan/carboxymethyl chitosan complex microcapsules and application in Lactobacillus casei ATCC 393. Carbohydr Polym [Internet]. 2011;83(4):1479-85. Available from: http://dx.doi.org/10.1016/j.carbpol.2010.09.053

[10] Chávarri M, Marañón I, Ares R, Ibáñez FC, Marzo F, Villarán M del C. Microencapsulation of a probiotic and prebiotic in alginate-chitosan capsules improves survival in simulated gastrointestinal conditions. Int J Food Microbiol [Internet]. 2010;142(1-2):185-9. Available from: http://dx.doi.org/10.1016/j.ijfoodmicro.2010.06.022

[11] Gbassi GK, Vandamme T. Probiotic encapsulation technology: From microencapsulation to release into the gut. Pharmaceutics. 2012;4(1):149-63.

[12] Amila Sholihat, Amila Gadri, Gita Cahya Eka Darma. Optimasi Kadar Konsentrat Likopen Terenkapsulasi Penyalut Alginat dan Kitosan. 2016;

[13] Bielecka M. Probiotics in food. Chem Funct Prop Food Components, Third Ed. 2006;413-26.

[14] Chan ES, Wong SL, Lee PP, Lee JS, Ti TB, Zhang Z, et al. Effects of starch filler on the physical properties of lyophilized calcium-alginate beads and the viability of encapsulated cells. Carbohydr Polym [Internet]. 2011;83(1):225-32. Available from: http://dx.doi.org/10.1016/j.carbpol.2010.07.044

[15] Gina Kholisoh. Uji Viabilitas Enkapsulasi Lactobacillus casei Menggunakan Matriks Kappa Karagenan Terhadap Simulasi Cairan Asam Lambung. Skripsi. 2016;

[16] Afzaal, M., Saeed, F., Arshad, M. U., Nadeem, M. T., Saeed, M., \& Tufail, T. (2018). The Effect of Encapsulation on The Stability of Probiotic Bacteria in Ice Cream and Simulated Gastrointestinal Conditions. Probiotics and Antimicrobial Proteins. doi:10.1007/s12602-018-9485-9.

[17] Carlos Pasqualin Cavalheiro, Mariana de Araújo Etchepare, Maria Fernanda da Silveira Cáceres de Menezes, Cristiano Ragagnin de Menezes, e Leadir Lucy Martins Fries. (2015). Encapsulation: an alternative for application of probiotic microorganisms in thermally processed foods. Doi: $10.5902 / 2179-460 X 19717$ 
[18] Mardliyati E, Muttaqien S El, Setyawati DR. Sintesis Nanopartikel Kitosan- Trypoly Phosphate Dengan Metode Gelasi Ionik: Pengaruh Konsentrasi Dan Rasio Volume Terhadap Karakteristik Partikel. Pros Pertem Ilm Ilmu Pengetah dan Teknol Bahan. 2012;90-3.

[19] Rokka S, Rantamäki P. Protecting probiotic bacteria by microencapsulation: Challenges for industrial applications. Eur Food Res Technol. 2010;231(1):1-12.

[20] Priyanka Singh, Pinki Saini,Shreyasi Dubey, Urvashi Srivastava. (2020). Microencapsulation of Probiotic by Exopolysaccharides-sodium Alginate dan Evaluation of their Survival in Simulated GI Conditions. Doi: 10.2174/1573401316666200123095452

[21] Solanki HK, Pawar DD, Shah DA, Prajapati VD, Jani GK, Mulla AM, et al. Development of microencapsulation delivery system for long-term preservation of probiotics as biotherapeutics agent. Biomed Res Int. 2013;2013.

[22] Rosburg, V., Boylston, T., \& White, P. (2010). Viability of Bifidobacteria Strains in Yogurt with Added Oat Beta-Glucan and Corn Starch during Cold Storage. Journal of Food Science, nono. doi:10.1111/j.1750-3841.2010.01620.x

[23] Ayumi, D. 2018. Pembuatan Dan Karakterisasi Nanopartikel Ekstrak Etanol Daun Ekor Naga (Rhaphidophora pinnata (L.f.) Schott) Menggunakan Metode Gelasi Ionik [skripsi]. Fakultas Farmasi USU, Medan.

[24] Mannuela, Novella. 2016. Preparasi dan Evaluasi Nanodroplet Azitromisin Kitosan dan Uji Aktivitas Antibakteri Terhadap Propionibacterium acnes. [skripsi]. Fakultas Kedokteran Universitas Tanjungpura.

[25] Heidebach T, Först P, Kulozik U. Influence of casein-based microencapsulation on freeze-drying and storage of probiotic cells. J Food Eng [Internet]. 2010;98(3):309-16. Available from: http://dx.doi.org/10.1016/j.jfoodeng.2010.01.003

[26] Sandoval-Castilla O, Lobato-Calleros C, García-Galindo HS, Alvarez-Ramírez J, Vernon-Carter EJ. Textural properties of alginate-pectin beads and survivability of entrapped Lb. casei in simulated gastrointestinal conditions and in yoghurt. 2010;43(1):111-117 DOI: 10.1016/j.foodres.2009.09.010

[27] Lucinda-Silva RM, Salgado HRN, Evangelista RC. Alginate-chitosan systems: In vitro controlled release of triamcinolone and in vivo gastrointestinal transit. Carbohydr Polym. 2010;81(2):260-8.

[28] Tim Sandle. 2016. Pharmaceutical Microbiology. ISBN 9781907568381

[29] D’Orazio, G., Di Gennaro, P., Boccarusso, M., Presti, I., Bizzaro, G., Giardina, S., ... La Ferla, B. (2015). Microencapsulation of new probiotic formulations for gastrointestinal delivery: in vitro study to assess viability and biological properties. Applied Microbiology and Biotechnology, 99(22), 9779-9789. doi:10.1007/s00253-015-6853-1

[30] Shah, N., Shah, T., \& Amin, A. (2011). Polysaccharides: a targeting strategy for colonic drug delivery. Expert Opinion on Drug Delivery, 8(6), 779-796. doi:10.1517/17425247.2011.574121

[31] Calinescu, C., Mondovi, B., Federico, R., Ispas-Szabo, P., \& Mateescu, M. A. (2012). Carboxymethyl starch: Chitosan monolithic matrices containing diamine oxidase and catalase for intestinal delivery. International Journal of Pharmaceutics, 428(1-2), 4856. doi:10.1016/j.ijpharm.2012.02.032

[32] Sumeisey, NG, 2019. Penyalutan bakteri asam laktat menggunakan nanopartikel kitosan. Pharmacon Volume 8 Nomor 4 November 2019

[33] Khosravavi Zanjani, Babak GT, Anausheh S, and Nima M. Microencaptulation of probiotics by calcium alginat-gelatized starch with citosan coating and evaluation of survival in simulated human gastrointestinal condition. 2014. Iranian Journal of Pharmaceutical Research. 13 (3): 843-852.

[34] Raphael D. Ayivi, Rabin Gyawali, Albert Krastanov, Sulaiman O. Aljaloud. Lactic Acid Bacteria: Food Safety and Human Health Applications. 2020;

[35] Masood, M. L., Qadir. M.I., Shirazi. J.H., and Khan, I.U. 2011. Beneficial effects of Lactic Acid Bacteria on human beings. Critical Rev.Microb.37(1): 91-98

[36] Chaudry R, Bamola VD, Panigrahi P. 2011. Host-microbe interactions in the gut : A Microbiologist's perspective. Dalam Nair dan Takeda. Probiotic foods in Health and Disease. 5. New Delhi (IN): CRC Press. 